U.S.

\title{
EC TRANSMISSION LINE
} RISK IDENTIFICATION AND MITIGATION ANALYSIS 
This report was prepared as an account of work sponsored by an agency of the United States Government. Neither the United States Government nor any agency thereof, nor any of their employees, makes any warranty, express or implied, or assumes any legal liability or responsibility for the accuracy, completeness, or usefulness of any information, apparatus, product, or process disclosed, or represents that its use would not infringe privately owned rights. Reference herein to any specific commercial product, process, or service by trade name, trademark, manufacturer, or otherwise, does not necessarily constitute or imply its endorsement, recommendation, or favoring by the United States Government or any agency thereof. The views and opinions of authors expressed herein do not necessarily state or reflect those of the United States Government or any agency thereof. 


\title{
EC Transmission Line Risk Identification and Mitigation Analysis
}

\author{
Tim Bigelow
}

Date Published: March 2012

\section{Prepared by}

OAK RIDGE NATIONAL LABORATORY

Oak Ridge, Tennessee 37831-6283

managed by

$$
\text { UT-BATTELLE, LLC }
$$

for the

U.S. DEPARTMENT OF ENERGY under contract DE-AC05-00OR22725 

US ITER 1050201-TD0001-R00

PA 5.2.P2.US.01.0

EC Transmission Line Risk Identification and Analysis

March 2012

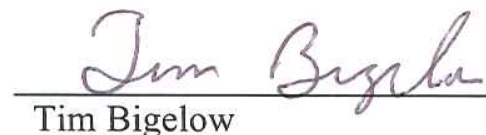

EC Transmission Lines Subject Matter Expert

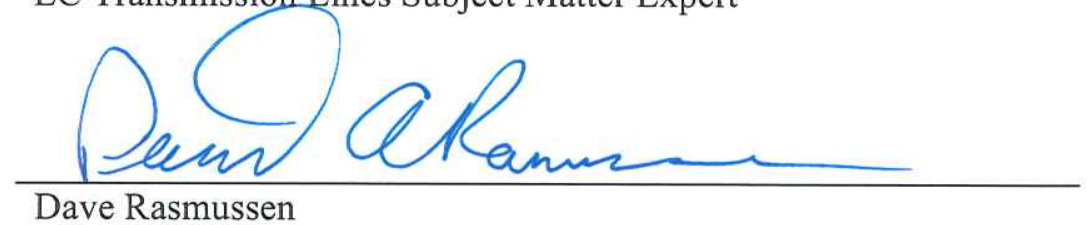

WBS Team Leader, US ITER ECH Transmission Lines

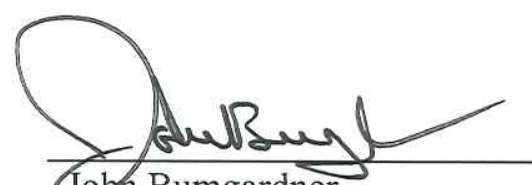

John Bumgardner

Nuclear Systems Division Director

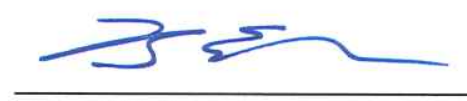

Brad Nelson

Chief Engineer, US ITER

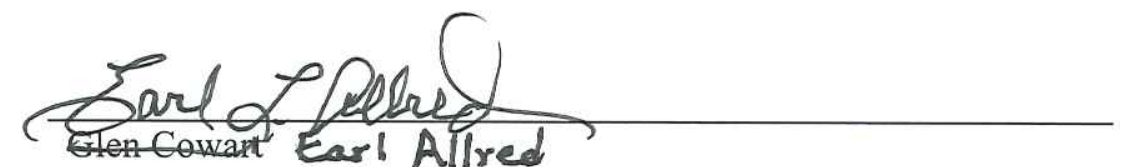

QA Responsible Officer, US ITER

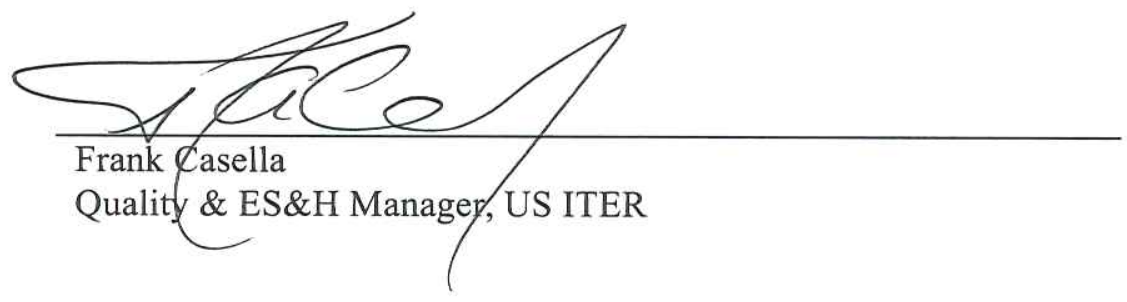

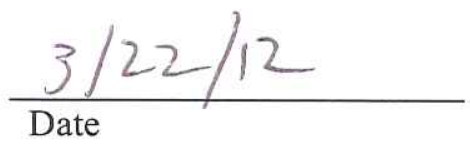
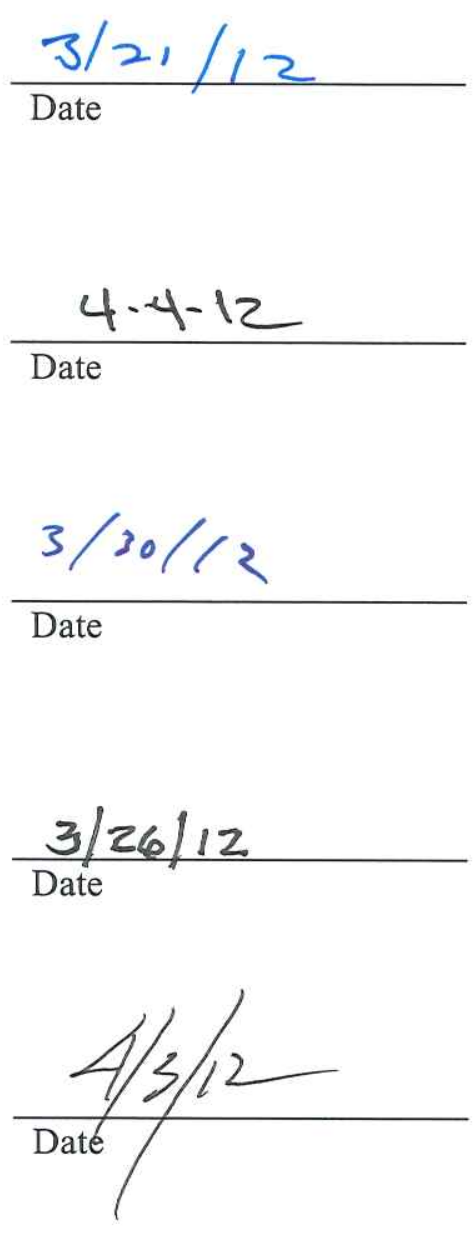



\section{REVISION RECORD}

\begin{tabular}{ccl}
\hline Revision & Date & Description of Changes \\
\hline 00 & $3 / 9 / 2012$ & Original \\
& & \\
\hline
\end{tabular}





\section{CONTENTS}

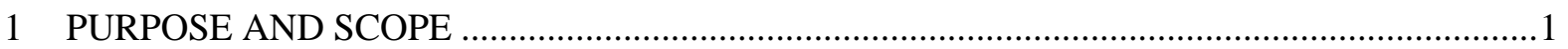

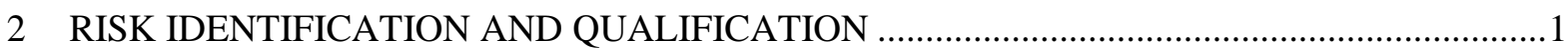

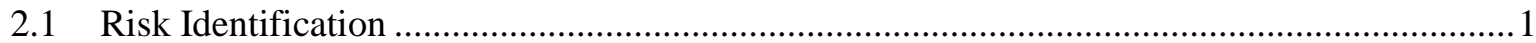

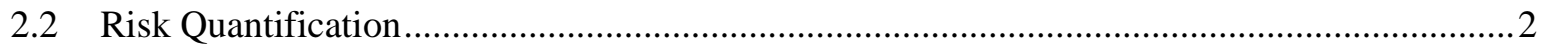

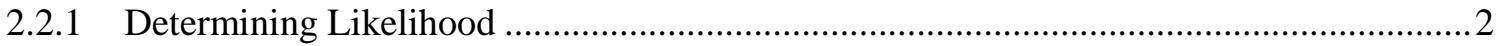

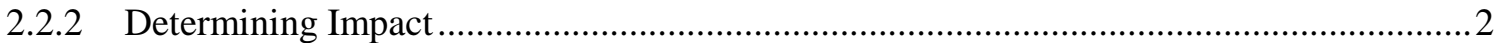

2.2.3 Overall Risk Rating ..................................................................................................

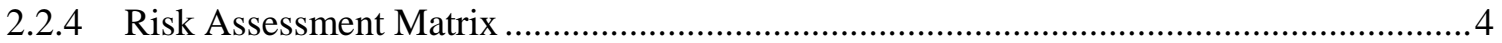

3 LISTING OF PROJECT RISKS ASSOCIATED WITH EC TRANSMISSION LINE .................4

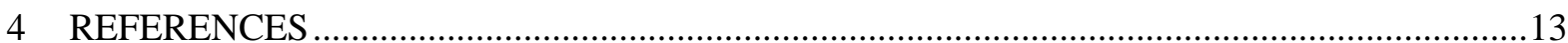





\section{PURPOSE AND SCOPE}

The purpose of this document is to assist in evaluating and planning for the cost, schedule, and technical project risks associated with the delivery and operation of the EC (Electron cyclotron) transmission line system. In general, the major risks that are anticipated to be encountered during the project delivery phase associated with the implementation of the Procurement Arrangement [1] for the EC transmission line system are associated with:

(1) Undefined or changing requirements (e.g., functional or regulatory requirements)

(2) Underperformance of prototype, first unit, or production components during testing

(3) Unavailability of qualified vendors for critical components

Technical risks associated with the design and operation of the system are also identified.

\section{RISK IDENTIFICATION AND QUALIFICATION}

\subsection{Risk Identification}

Risk is defined as an uncertain event or condition that, if it occurs, has a positive or negative effect on a project objective. Risk is an inherent part of all activities, whether the activity is simple and small, or large and complex. The relative size and/or complexity of an activity may or may not be an indicator of the potential degree of risk associated with that activity.

There are two main sources of risks that can affect the ITER Project: (1) Event risks, and (2) Uncertainty risks. Both types of risks are covered in this document.

Event Risks are potential occurrences that can have an impact on project scope, increase project cost and/or schedule, reduce safety margins, or reduce the quality of the final product. Event Risks can be caused both internally and externally and, in many cases, can be foreseen by project management within some reasonable planning horizon. Examples of foreseeable events might include instabilities in qualified craft labor at a construction site, or the ability of component suppliers to meet their delivery schedules. Event risks are typically stated in the following manner: "As result of , there is a risk that. , resulting in. .."

Event Risks include the following categories:

- Technical

- Design

- Safety

- Environment

- Technology

- Interfaces

- Programmatic

- Sequencing

- Delays in procurement

- Delays in delivery of equipment

- Non availability of buildings in time for science 
Uncertainty risks are the result of variability of the estimating data used to create the project baseline cost and schedule estimates. This primarily covers uncertainties in project cost and schedule estimates that result from:

- Errors and omissions

- Inflation

- Adverse weather

- Pricing variances

- Quantity variances

- Complexity

- Facility access

\subsection{Risk Quantification}

Risk quantification involves assessing risks to determine potential project consequences. This consists of determining the likelihood of the identified risk actually occurring, assessing the impact if it does occur, and then assigning an overall rating to the risk. The guidelines for use of the ITER Project risk assessment matrix are given in [2], and restated below.

\subsubsection{Determining Likelihood}

Risks are categorized by likelihood or probability of occurrence. Generally, a risk that is determined to be in the "Very Likely" to occur category is one that has a probability of $80 \%$ or greater of occurrence. A risk that is "Likely" to occur is one that has a probability between $40 \%-80 \%$. A risk that has less than a $40 \%$ chance of occurring is categorized as "Unlikely." The probability categories are summarized in Table 2.1.

Table 2.1. Probability of Occurrence Matrix

\begin{tabular}{|l|l|l|}
\hline $\begin{array}{l}\text { Probability of } \\
\text { Occurrence }\end{array}$ & Qriteria \\
\hline Qualitative & $>0.8$ & $\begin{array}{l}\text { The probability of occurrence in the life of the project } \\
\text { is judged to be greater than } 80 \% .\end{array}$ \\
\hline Very Likely (5) & $>0.4$ but $<0.8$ & $\begin{array}{l}\text { The probability of occurrence in the life of the project } \\
\text { is judged to be greater than } 40 \% \text { but less than } 80 \% .\end{array}$ \\
\hline Likely (4) & $>0.1$ but $<0.4$ & $\begin{array}{l}\text { The probability of occurrence in the life of the project } \\
\text { is judged to be greater than } 10 \% \text { but less than } 40 \% .\end{array}$ \\
\hline Unlikely (3) & $>0.01$ but $<0.1$ & $\begin{array}{l}\text { The probability of occurrence in the life of the project } \\
\text { is judged to be greater than } 1 \% \text { but less than } 10 \% .\end{array}$ \\
\hline Very Unlikely (2) & $\begin{array}{l}\text { The probability of occurrence in the life of the project } \\
\text { is judged to be less than } 1 \% .\end{array}$ \\
\hline Not Credible (1) & $<0.01$ & \\
\hline
\end{tabular}

\subsubsection{Determining Impact}

Risks can also have varying impacts/consequences on the project. If a risk occurs, a negative consequence usually results. The consequence will typically adversely affect the technical accomplishment, result in a schedule or milestone slip, and/or cause a cost impact. The degree of the consequence is measured. Table 2.2 is used in making the determination of the impact to the project. 
Table 2.2. Risk Impact Matrix

\begin{tabular}{|c|c|c|c|}
\hline $\begin{array}{l}\text { Consequence } \\
\text { Category }\end{array}$ & $\begin{array}{l}\text { Cost: Impact on project } \\
\text { contingency }\end{array}$ & $\begin{array}{c}\text { Schedule: IPS-ITER } \\
\text { Integrated Project } \\
\text { Schedule } \\
\end{array}$ & $\begin{array}{c}\text { Technical: Impact on } \\
\text { performance }\end{array}$ \\
\hline Negligible (1) & $\begin{array}{l}\text { There is negligible change } \\
\text { in Construction or life-cycle } \\
\text { cost (i.e., }<1 \% \text { of } \\
\text { Negotiated kIUA). }<0.01\end{array}$ & $\begin{array}{l}\text { The effects of this risk } \\
\text { would only be felt by } \\
\text { activities not near the } \\
\text { Critical Path, and the } \\
\text { impacts are mitigated below } \\
\text { Level } 3 \text { milestones. } \\
\text { Schedule impacts can be } \\
\text { covered with available } \\
\text { float. }\end{array}$ & $\begin{array}{l}\text { Negligible degradation, } \\
\text { performance falls below } \\
\text { upper end of goal; project } \\
\text { goals can still be met. }\end{array}$ \\
\hline Marginal (2) & $\begin{array}{l}\text { There is a marginal impact } \\
\text { in Construction or life-cycle } \\
\text { cost between } 1-10 \% \text { of } \\
\text { Negotiated kIUA. Costs } \\
\text { marginally exceed budget. } \\
>0.01 \text { but }<0.1\end{array}$ & $\begin{array}{l}\text { Activities on the Critical } \\
\text { Path and IO Milestones are } \\
\text { NOT affected, but activities } \\
\text { near the Critical Path or } \\
\text { Level } 3 \text { milestones could be } \\
\text { affected. (>1 week to } \\
1 \text { Month) }\end{array}$ & $\begin{array}{l}\text { Marginal performance } \\
\text { shortfall, but workarounds } \\
\text { available; risks might impact } \\
\text { project goals if not } \\
\text { mitigated. }\end{array}$ \\
\hline Significant (3) & $\begin{array}{l}\text { Cost estimates significantly } \\
\text { exceed budget. There is a } \\
\text { potential for a }>10 \% \text { kIUA } \\
\text { impact of a procurement } \\
\text { arrangement allocation } \\
\text { budget or cost change (i.e., } \\
\text { either increase or decrease) } \\
\text { in the Construction or } \\
\text { lifecycle cost of an } \\
\text { individual subsystem. }>0.1 \\
\text { but }<0.2\end{array}$ & $\begin{array}{l}\text { Any impact to an IO } \\
\text { Milestone (Level 2). } \\
>1 \text { Months delay in delivery } \\
\text { of an item ON the project's } \\
\text { Critical Path, or > 1- } \\
3 \text { Months of the time } \\
\text { allocated to an activity } \\
\text { NEAR the Critical Path. }\end{array}$ & $\begin{array}{l}\text { Significant degradation in } \\
\text { modification/project } \\
\text { technical performance. } \\
\text { Significant threat to facility } \\
\text { mission, environment or } \\
\text { people, requires some } \\
\text { equipment redesign or } \\
\text { repair, significant } \\
\text { environmental remediation } \\
\text { or causes injury requiring } \\
\text { medical treatment. Project } \\
\text { goals may not be met } \\
\text { (essential performance } \\
\text { parameter not met). }\end{array}$ \\
\hline Critical (4) & $\begin{array}{l}\text { Cost estimates seriously } \\
\text { exceed the budget. There is } \\
\text { a potential for a }>20 \% \\
\text { kIUA impact of a } \\
\text { procurement arrangement } \\
\text { allocation budget or cost } \\
\text { change (i.e., either increase } \\
\text { or decrease) in the } \\
\text { Construction or lifecycle } \\
\text { cost of an individual } \\
\text { subsystem. }>0.2 \text { but }<0.4\end{array}$ & $\begin{array}{l}\text { Any impact to an IO } \\
\text { Milestone (Level 1). } \\
>3 \text { Months delay in } \\
\text { delivery of an item ON the } \\
\text { project's Critical Path, or > } \\
\text { 3-6 months of the time } \\
\text { allocated to an activity } \\
\text { NEAR the Critical Path. }\end{array}$ & $\begin{array}{l}\text { Serious threat to facility } \\
\text { mission, environment, or } \\
\text { people, possibly completing } \\
\text { only portions of the mission } \\
\text { or requiring major } \\
\text { equipment redesign or } \\
\text { rebuilding, extensive } \\
\text { environmental remediation } \\
\text { or intensive medical care for } \\
\text { life-threatening injury. }\end{array}$ \\
\hline Crisis (5) & $\begin{array}{l}\text { Cost estimates } \\
\text { unacceptably exceed the } \\
\text { budget. There is a potential } \\
\text { for a }>40 \% \text { kIUA impact of } \\
\text { a procurement arrangement } \\
\text { allocation budget or cost } \\
\text { change (i.e., either increase } \\
\text { or decrease) in the } \\
\text { Construction or lifecycle } \\
\text { cost of an individual } \\
\text { subsystem. }>0.4\end{array}$ & $\begin{array}{l}\text { Any impact to an IO } \\
\text { Milestone (Level 0). } \\
>6 \text { Months delay in } \\
\text { delivery of an item ON the } \\
\text { project's Critical Path. }\end{array}$ & $\begin{array}{l}\text { Catastrophic threat to } \\
\text { facility(s), mission, } \\
\text { environment, or people, } \\
\text { possibly causing loss of } \\
\text { mission, long-term } \\
\text { environmental abandonment } \\
\text { and/or death. }\end{array}$ \\
\hline
\end{tabular}




\subsubsection{Overall Risk Rating}

A risk's probability must be weighed against its potential impact in order to assess the action necessary for dealing with the risk. A risk that has a high probability of occurrence can have a negligible impact on the project. Conversely, a low probability risk can have a high impact on the project's technical accomplishment, schedule, or cost. Each project risk is assigned an overall risk rating as Low, Medium, High, or Very High based on the likelihood of occurrence and consequences. Table 2.3 relates the overall risk ranking with the required action.

Table 2.3. Overall Risk Ranking vs Action

\begin{tabular}{|l|l|}
\hline Level & Action \\
\hline Low & $\begin{array}{l}\text { Risk is included in the risk file and reviewed by DA TRO concerned. } \\
\text { Actions are evaluated in order to reduce the risk. } \\
\text { Any escalation is reported to the DDG, or DA Head. }\end{array}$ \\
\hline Medium & $\begin{array}{l}\text { A technical owner is appointed to monitor the risk evolution and report to the DA TRO and } \\
\text { the RO concerned. } \\
\text { Actions are evaluated in order to reduce the risk. }\end{array}$ \\
\hline Hery High & $\begin{array}{l}\text { Same as level MEDIUM plus definition of specific mitigation actions. } \\
\text { These actions are defined by the DA TRO (or DDG if a Project-level type risk) concerned } \\
\text { with the risk, who identifies possible trigger events to start them. } \\
\text { The owner monitors the risks and these trigger events. }\end{array}$ \\
$\begin{array}{l}\text { The risk owner is the DA TRO (as designated directly by the DA Head), who closely } \\
\text { monitors the effectiveness of the mitigation actions at each project review meeting. These } \\
\text { risks require close IO monitoring. These risks also require the identification of a mitigation } \\
\text { strategy (recorded on the risk register), and regular review at project management meetings } \\
\text { and IO-DA meetings. } \\
\text { Frequent high-level visibility of these risks is required. Elimination and/or mitigation of risks } \\
\text { rated as "Very High" overall is a priority. } \\
\text { Planned mitigation actions are started as scheduled. }\end{array}$ \\
\hline
\end{tabular}

\subsubsection{Risk Assessment Matrix}

The ITER Project employs an established risk methodology for consistency and quality in the risk management process, as represented by the risk assessment matrix shown in Table 2.4. The y-axis determination (Likelihood of occurrence) is first made for an identified risk, followed by the x-Axis (Impact/Consequence). The table then yields an "overall risk rating.”

Table 2.4. Risk Assessment Matrix

\begin{tabular}{|l|c|c|c|c|c|}
\hline \multicolumn{7}{|l|}{ Risk Assessment Matrix - Assigning an Overall Risk Rating } \\
\hline \multirow{2}{*}{$\begin{array}{l}\text { Likelihood of } \\
\text { Occurrence }\end{array}$} & Baseline Impact/Consequence \\
\cline { 2 - 6 } & Negligible (1) & Marginal (2) & Significant (3) & Critical (4) & Crisis (5) \\
\hline Very likely (5) & High & High & Very High & Very High & Very High \\
\hline Likely (4) & Medium & High & High & Very High & Very High \\
\hline Unlikely (3) & Medium & Medium & High & High & Very High \\
\hline Very Unlikely (2) & Low & Medium & Medium & High & High \\
\hline Not Credible (1) & Low & Low & Medium & Medium & High \\
\hline
\end{tabular}

\section{LISTING OF PROJECT RISKS ASSOCIATED WITH EC TRANSMISSION LINE}

Table 3.1 identifies and evaluates EC transmission line project, design, manufacturing, operational, and functional risks [3]. 
Project Risks

Table 3.1. EC Transmission Line Risks

\begin{tabular}{|c|c|c|c|c|c|c|c|c|c|c|c|c|c|c|c|c|}
\hline \multirow{2}{*}{\multicolumn{8}{|c|}{$\begin{array}{l}\text { Risk Analysis and Mitigation Form } \\
\text { Responsible Manager; Gandini }\end{array}$}} & \multicolumn{9}{|c|}{ Procurement Arrangement: ECH PA 5.2.P2.US.01.0 } \\
\hline \multicolumn{15}{|c|}{ Responsible Manager: Gandini } & & \\
\hline & & & & & \multicolumn{4}{|c|}{ Revision Number: } & 0 & \multicolumn{7}{|l|}{ Date: January 2012} \\
\hline \multicolumn{9}{|c|}{ Risk Identification \& Evaluation } & \multicolumn{4}{|c|}{ Risk Disposition } & \multicolumn{4}{|c|}{ Risk Rating After Mitigation } \\
\hline \multirow{4}{*}{ 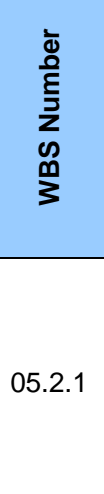 } & 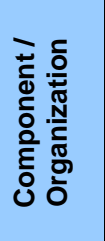 & 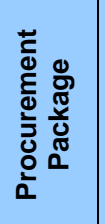 & $\begin{array}{l}\text { Risk } \\
\text { Owner }\end{array}$ & Description of Risk & \multirow{4}{*}{ 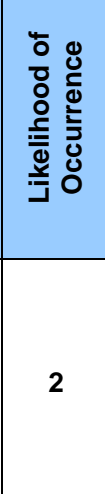 } & \multicolumn{2}{|c|}{ Impact } & $\begin{array}{c}\text { Overall } \\
\text { Risk } \\
\text { Rating }\end{array}$ & 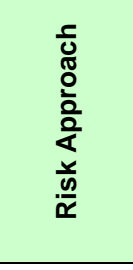 & \multirow{4}{*}{$\begin{array}{l}\begin{array}{l}\text { Mitigation Strategy (Required for High } \\
\text { Level Risks) }\end{array} \\
\begin{array}{l}\text { Ensure that USIPO resources are } \\
\text { sufficient for the duration of the R\&D } \\
\text { program }\end{array} \\
\end{array}$} & 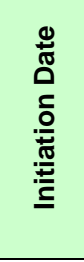 & 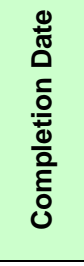 & \multirow{4}{*}{ 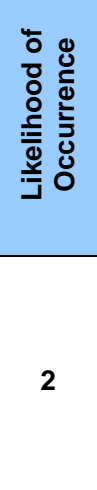 } & \multicolumn{2}{|l|}{ Impact } & $\begin{array}{c}\text { Overall } \\
\text { Risk } \\
\text { Rating }\end{array}$ \\
\hline & \multirow{3}{*}{ CHD } & \multirow{3}{*}{ TL } & \multirow{3}{*}{$\begin{array}{l}\text { IOI } \\
\text { USIPO }\end{array}$} & \multirow{3}{*}{$\begin{array}{l}\text { If resources required for } R \& D \text { are not } \\
\text { available or are not available on time, then } \\
\text { there could be a cost and/or schedule } \\
\text { impact. }\end{array}$} & & Technical & 2 & \multirow{3}{*}{ Medium } & & & & & & Technical & 1 & \\
\hline & & & & & & Schedule & 3 & & Mitigate & & & & & Schedule & 2 & Medium \\
\hline & & & & & & Cost & 2 & & & & & & & Cost & 1 & \\
\hline & & & & If the functional requirements are ill- & & Technical & 2 & & & & & & & Technical & 2 & \\
\hline 05.2 .1 & $\mathrm{CHD}$ & TL & $\begin{array}{l}\text { IOI } \\
\text { USIPO }\end{array}$ & $\begin{array}{l}\text { available, then there could be a cost } \\
\text { and//or schedule impact due to redesian }\end{array}$ & 3 & Schedule & 3 & Medium & Mitigate & $\begin{array}{l}\text { documentation (service handbooks) to } \\
\text { provide clarification of functional }\end{array}$ & & & 2 & Schedule & 2 & Medium \\
\hline & & & & and/or rework. & & Cost & 2 & & & 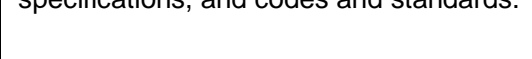 & & & & Cost & 2 & \\
\hline & & & & If main interfaces (i.e., Gyrotron, Cooling & & Technical & 2 & & & & & & & Technical & 2 & \\
\hline 05.2 .1 & $\mathrm{CHD}$ & $\mathrm{TL}$ & $\begin{array}{l}\text { IOI } \\
\text { USIPO }\end{array}$ & $\begin{array}{l}\text { are changed during design/manufacture } \\
\text { phases, then there could be a cost and/or }\end{array}$ & 3 & Schedule & 3 & Medium & Avoid & $\begin{array}{l}\text { Rely on PCR process and interface } \\
\text { summit to minimize impacts. }\end{array}$ & & & 2 & Schedule & 1 & Medium \\
\hline & & & & documentation. & & Cost & 2 & & & & & & & Cost & 2 & \\
\hline & & & & & & Technical & 3 & & & & & & & Technical & 1 & \\
\hline 05.2 .1 & CHD & $\mathrm{TL}$ & 10 & $\begin{array}{l}\text { IO/ EC to support Transmission Line } \\
\text { activities, then there could be a schedule }\end{array}$ & 3 & Schedule & 3 & High & Avoid & $\begin{array}{l}\text { previous development and installation } \\
\text { experience should be developed and }\end{array}$ & & & 2 & Schedule & 1 & Low \\
\hline & & & & & & Cost & 3 & & & & & & & Cost & 1 & \\
\hline & & & & & & Technical & 2 & & & Establish supplier list for all components. & & & & Technical & 1 & \\
\hline 05.2 .1 & CHD & $\mathrm{TL}$ & $\begin{array}{l}10 / \\
\text { USIPO }\end{array}$ & $\begin{array}{l}\text { from single suppliers, then cost and/or } \\
\text { schedule could be affected by necessity to } \\
\text { sidentify andlor train alternate sunpliers }\end{array}$ & 3 & Schedule & 3 & Medium & Mitigate & $\begin{array}{l}\text { multiple suppliers during design and } \\
\text { testing phases. Develop alternative }\end{array}$ & & & 2 & Schedule & 1 & Low \\
\hline & & & & & & Cost & 2 & & & & & & & Cost & 1 & \\
\hline & & & & & & Technical & 2 & & & & & & & Technical & 1 & \\
\hline 05.2 .1 & CHD & $\mathrm{TL}$ & 10 & $\begin{array}{l}\text { construction schedules and/or costs may } \\
\text { increase or system functionality could be }\end{array}$ & 3 & Schedule & 3 & Medium & Avoid & 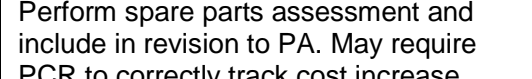 & & & 2 & Schedule & 1 & Low \\
\hline & & & & & & Cost & 2 & & & & & & & Cost & 1 & \\
\hline
\end{tabular}




\begin{tabular}{|c|c|c|c|c|c|c|c|c|c|c|c|c|c|c|c|c|}
\hline \multirow{2}{*}{\multicolumn{8}{|c|}{ Risk Analysis and Mitigation Form }} & \multicolumn{9}{|c|}{ Procurement Arrangement: ECH PA 5.2.P2.US.01.0 } \\
\hline \multicolumn{15}{|c|}{ Responsible Manager: Gandini } & & \\
\hline & & & & & \multicolumn{4}{|c|}{ Revision Number: } & 0 & \multicolumn{7}{|l|}{ Date: January 2012} \\
\hline \multicolumn{9}{|c|}{ Risk Identification \& Evaluation } & \multicolumn{4}{|c|}{ Risk Disposition } & \multicolumn{4}{|c|}{ Risk Rating After Mitigation } \\
\hline \multirow{4}{*}{ 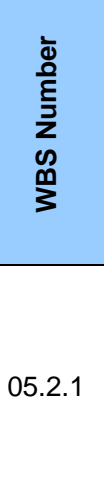 } & \multirow{4}{*}{ 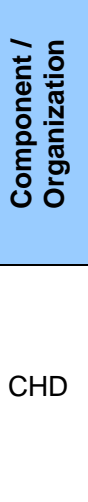 } & \multirow{4}{*}{ 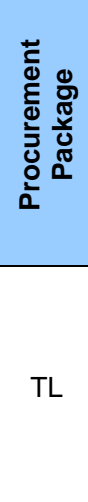 } & \multirow{4}{*}{$\begin{array}{c}\begin{array}{c}\text { Risk } \\
\text { Owner }\end{array} \\
10\end{array}$} & Description of Risk & \multirow{4}{*}{ 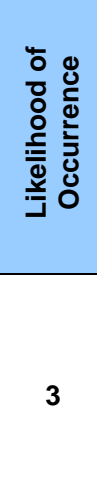 } & \multicolumn{2}{|c|}{ Impact } & \multirow{4}{*}{$\begin{array}{c}\begin{array}{c}\text { Overall } \\
\text { Risk } \\
\text { Rating }\end{array} \\
\\
\text { Medium }\end{array}$} & \multirow{4}{*}{ 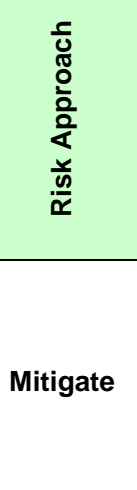 } & \multirow{4}{*}{$\begin{array}{l}\begin{array}{l}\text { Mitigation Strategy (Required for High } \\
\text { Level Risks) }\end{array} \\
\begin{array}{l}\text { Expedite PCR process and rely on } \\
\text { interface summit to provide timely } \\
\text { information. }\end{array}\end{array}$} & \multirow[t]{4}{*}{ 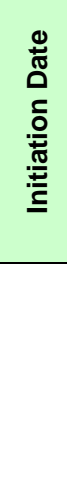 } & 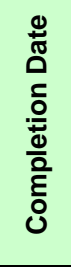 & \multirow{4}{*}{ 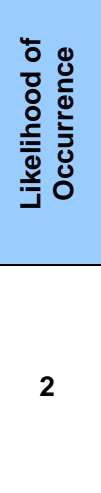 } & \multicolumn{2}{|c|}{ Impact } & $\begin{array}{c}\text { Overall } \\
\text { Risk } \\
\text { Rating }\end{array}$ \\
\hline & & & & \multirow{3}{*}{$\begin{array}{l}\text { If qualification requirements for critical } \\
\text { components are not defined or not defined } \\
\text { in a timely manner, there could be a cost } \\
\text { and/or schedule impact due to redesign or } \\
\text { rework. }\end{array}$} & & Technical & 2 & & & & & & & Technical & 2 & \multirow{3}{*}{ Medium } \\
\hline & & & & & & Schedule & 2 & & & & & & & Schedule & 2 & \\
\hline & & & & & & Cost & 2 & & & & & & & Cost & 2 & \\
\hline \multirow{3}{*}{05.2 .1} & \multirow{3}{*}{ CHD } & \multirow{3}{*}{$\mathrm{TL}$} & \multirow{3}{*}{$\begin{array}{l}\text { IO/ } \\
\text { USIPO }\end{array}$} & \multirow{3}{*}{$\begin{array}{l}\text { If R\&D of critical components is more } \\
\text { expensive/takes longer than planned, then } \\
\text { there could be a cost and/or schedule } \\
\text { impact. }\end{array}$} & \multirow{3}{*}{4} & Technical & 2 & & & Continuation of prototype testing and use & & & & Technical & 1 & \\
\hline & & & & & & Schedule & 3 & High & Mitigate & $\begin{array}{l}\text { prototypes helps to identify such } \\
\text { components and to accurately estimate }\end{array}$ & & & 3 & Schedule & 2 & Medium \\
\hline & & & & & & Cost & 3 & & & cost and time. & & & & Cost & 2 & \\
\hline & & & & $\begin{array}{l}\text { If thermal expansion of waveguide on long } \\
\text { runs appears excessive due to large }\end{array}$ & & Technical & 3 & & & $\begin{array}{l}\text { Mitigate by designing sufficient margin } \\
\text { on wavequide cooling and designing and }\end{array}$ & & & & Technical & 2 & \\
\hline 05.2 .1 & $\mathrm{CHD}$ & $\mathrm{TL}$ & 10 & $\begin{array}{l}\text { heating during operation, then excessive } \\
\text { mode conversion and efficiency loss would }\end{array}$ & 3 & Schedule & 2 & High & Mitigate & $\begin{array}{l}\text { including waveguide expansion unit to } \\
\text { accommodate axial movement due to }\end{array}$ & & & 2 & Schedule & 2 & Medium \\
\hline & & & & $\begin{array}{l}\text { result, and system functionality could be } \\
\text { affected. }\end{array}$ & & Cost & 3 & & & of temperature controls on water cooling. & & & & Cost & 2 & \\
\hline & & & & If miter bend mirror & & Technical & 3 & & & Qualify conservative design with high & & & & Technical & 2 & \\
\hline 05.2 .1 & $\mathrm{CHD}$ & $\mathrm{TL}$ & $\begin{array}{l}\text { III } \\
\text { USIPO }\end{array}$ & $\begin{array}{l}\text { for } 2 \mathrm{MW} \text { CW operation, then mirror } \\
\text { overheating and distortion would result, }\end{array}$ & 3 & Schedule & 2 & High & Mitigate & $\begin{array}{l}\text { thermal//mechanical modeling underway } \\
\text { and perform high power tests at } 2 \mathrm{MW}\end{array}$ & & & 2 & Schedule & 2 & Medium \\
\hline & & & & & & Cost & 2 & & & ring setup on a test stand. & & & & Cost & 2 & \\
\hline & & & & If polarizer miter bend mirror cooling is & & Technical & 3 & & & Qualify conservative design with high & & & & Technical & 2 & \\
\hline 05.2 .1 & $\mathrm{CHD}$ & $\mathrm{TL}$ & $\begin{array}{l}\text { IOI } \\
\text { USIPO }\end{array}$ & $\begin{array}{l}\text { mirror overheeating and distortion would } \\
\text { result and system functionality could be }\end{array}$ & 4 & Schedule & 2 & High & Mitigate & $\begin{array}{l}\text { thermal//mechanical modeling underway } \\
\text { and perform high power tests at } 2 \mathrm{MW}\end{array}$ & & & 3 & Schedule & 2 & Medium \\
\hline & & & & affected & & Cost & 2 & & & ring setup on a test stand. & & & & Cost & 2 & \\
\hline
\end{tabular}









\section{Manufacturing Risks}

\begin{tabular}{|c|c|c|c|c|c|c|c|c|c|c|c|c|c|c|c|c|}
\hline \multicolumn{8}{|c|}{ Title: EC Transmission Line risk log } & \multicolumn{9}{|c|}{ Procurement Arrangement: ECH PA 5.2.P2.US.01.0 } \\
\hline \multicolumn{17}{|c|}{ Responsible Manager: Gandini } \\
\hline & & & & & \multicolumn{4}{|c|}{ Revision Number: } & 0 & \multicolumn{7}{|l|}{ Date: January 2012} \\
\hline \multicolumn{9}{|c|}{ Risk Identification \& Evaluation } & \multicolumn{4}{|c|}{ Risk Disposition } & \multicolumn{4}{|c|}{ Risk Rating After Mitigation } \\
\hline \multirow{4}{*}{ 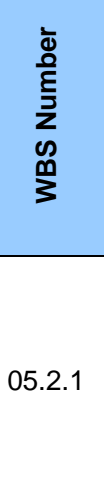 } & \multirow{4}{*}{ 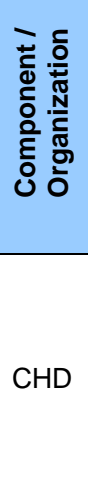 } & \multirow{4}{*}{ 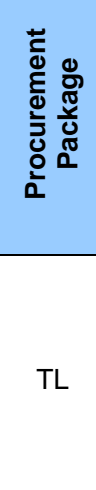 } & \multirow{4}{*}{$\begin{array}{c}\begin{array}{c}\text { Risk } \\
\text { Owner }\end{array} \\
\begin{array}{c}\text { USIPO / } \\
\text { IO }\end{array}\end{array}$} & Description of Risk & \multirow{4}{*}{ 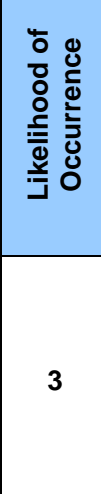 } & \multicolumn{2}{|c|}{ Impact } & $\begin{array}{c}\text { Overall } \\
\text { Risk } \\
\text { Rating }\end{array}$ & \multirow{4}{*}{ 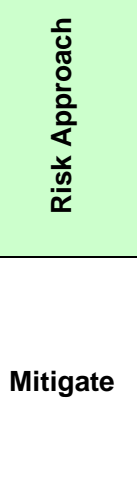 } & \multirow{4}{*}{\begin{tabular}{|l}
$\begin{array}{l}\text { Mitigation Strategy (Required for High } \\
\text { Level Risks) }\end{array}$ \\
$\begin{array}{l}\text { Expedite PCR process and rely on } \\
\text { interface summit to provide timely } \\
\text { information. }\end{array}$ \\
\end{tabular}} & 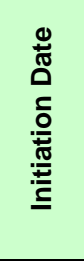 & 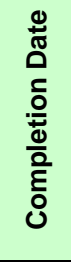 & \multirow{4}{*}{ 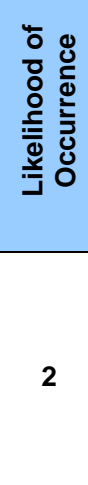 } & \multicolumn{2}{|c|}{ Impact } & $\begin{array}{c}\text { Overall } \\
\text { Risk } \\
\text { Rating }\end{array}$ \\
\hline & & & & \multirow{3}{*}{$\begin{array}{l}\text { If qualification requirements for critical } \\
\text { components are not provided until the } \\
\text { manufacturing process, then there could } \\
\text { be a cost and/or schedule impact. }\end{array}$} & & Technical & 3 & \multirow{3}{*}{ High } & & & & & & Technical & 2 & \multirow{3}{*}{ Medium } \\
\hline & & & & & & Schedule & 3 & & & & & & & Schedule & 2 & \\
\hline & & & & & & Cost & 3 & & & & & & & Cost & 2 & \\
\hline \multirow{3}{*}{05.2 .1} & \multirow{3}{*}{ CHD } & \multirow{3}{*}{ TL } & & & & Technical & 3 & & & & & & & Technical & 1 & \\
\hline & & & USIPO & $\begin{array}{l}\text { defined prior to or during manufacturing, } \\
\text { then there could be a cost/and or schedule }\end{array}$ & 3 & Schedule & 3 & High & Mitigate & $\begin{array}{l}\text { Develop and implement a test program } \\
\text { during development stage to ensure that } \\
\text { functional requirements are met }\end{array}$ & & & 1 & Schedule & 2 & Low \\
\hline & & & & & & Cost & 3 & & & & & & & Cost & 2 & \\
\hline & & & & & & Technical & 3 & & & Perform prototype testing based on & & & & Technical & 1 & \\
\hline 05.2 .1 & $\mathrm{CHD}$ & $\mathrm{TL}$ & USIPO & $\begin{array}{l}\text { drawings are not available in time for the } \\
\text { final design, then there could be a cost }\end{array}$ & 3 & Schedule & 3 & High & Mitigate & $\begin{array}{l}\text { final design, undergo tender process with } \\
\text { sound evaluation process; require }\end{array}$ & & & 1 & Schedule & 2 & Low \\
\hline & & & & & & Cost & 3 & & & $\begin{array}{l}\text { process. } \\
\text { pos }\end{array}$ & & & & Cost & 1 & \\
\hline & & & & & & Technical & 2 & & & & & & & Technical & 1 & \\
\hline 05.2 .1 & $\mathrm{CHD}$ & TL & USIPO & $\begin{array}{l}\text { subcomponents from other suppliers that } \\
\text { fail to meet requirements then there could }\end{array}$ & 2 & Schedule & 2 & Medium & Mitigate & $\begin{array}{l}\text { Sub-component manufacture performed } \\
\text { (or strongly monitored) by assembly } \\
\text { contractor }\end{array}$ & & & 1 & Schedule & 1 & Low \\
\hline & & & & & & Cost & 2 & & & & & & & Cost & 1 & \\
\hline & & & & If only a single industry is available for & & Technical & 1 & & & & & & & Technical & 1 & \\
\hline 05.2 .1 & $\mathrm{CHD}$ & TL & USIPO & $\begin{array}{l}\text { some wavegulde components, then there } \\
\text { could be a cost and/or schedule impact } \\
\text { due to necessity to identify and/or train }\end{array}$ & 2 & Schedule & 2 & Medium & Mitigate & $\begin{array}{l}\text { Procure prototylye components from } \\
\text { multiple suppliers during design and } \\
\text { testing phase prior to final design }\end{array}$ & & & 1 & Schedule & 1 & Low \\
\hline & & & & & & Cost & 2 & & & & & & & Cost & 2 & \\
\hline & & & & & & Technical & 2 & & & & & & & Technical & 1 & \\
\hline 05.2.1 & $\mathrm{CHD}$ & $\mathrm{TL}$ & USIPO & $\begin{array}{l}\text { waveguide, then there could be a cost } \\
\text { and/or schedule impact due to necessity to }\end{array}$ & 3 & Schedule & 2 & Medium & Mitigate & $\begin{array}{l}\text { fabricated to print. Procure and test } \\
\text { prototype of final design prior to }\end{array}$ & & & 1 & Schedule & 2 & Low \\
\hline & & & & & & Cost & 2 & & & & & & & Cost & 2 & \\
\hline
\end{tabular}




\begin{tabular}{|c|c|c|c|c|c|c|c|c|c|c|c|c|c|c|c|c|}
\hline \multirow{2}{*}{\multicolumn{8}{|c|}{$\begin{array}{l}\text { Risk Analysis and Mitigation Form } \\
\text { Responsible Manager: Gandini }\end{array}$}} & \multicolumn{9}{|c|}{ Procurement Arrangement: ECH PA 5.2.P2.US.01.0 } \\
\hline \multicolumn{15}{|c|}{ Responsible Manager: Gandini } & & \\
\hline & & & & & \multicolumn{4}{|c|}{ Revision Number: } & 0 & \multicolumn{7}{|l|}{ Date: January 2012} \\
\hline \multicolumn{9}{|c|}{ Risk Identification \& Evaluation } & \multicolumn{4}{|c|}{ Risk Disposition } & \multicolumn{4}{|c|}{ Risk Rating After Mitigation } \\
\hline 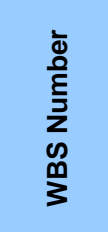 & 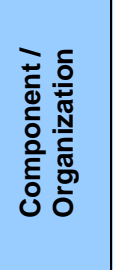 & 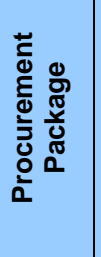 & $\begin{array}{l}\text { Risk } \\
\text { Owner }\end{array}$ & Description of Risk & \multirow{4}{*}{ 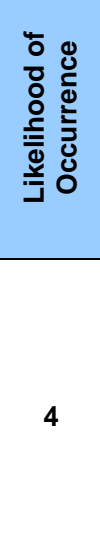 } & \multicolumn{2}{|c|}{ Impact } & \multirow{4}{*}{$\begin{array}{c}\begin{array}{c}\text { Overall } \\
\text { Risk } \\
\text { Rating }\end{array} \\
\text { High }\end{array}$} & \multirow{4}{*}{ 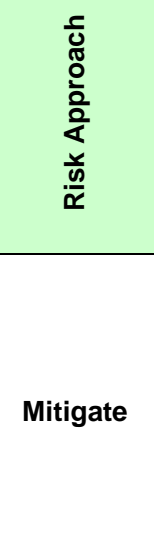 } & \multirow{4}{*}{$\begin{array}{l}\text { Mitigation Strategy (Required for High } \\
\text { Level Risks) }\end{array}$} & 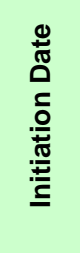 & 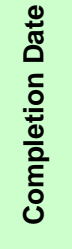 & \multirow{4}{*}{ 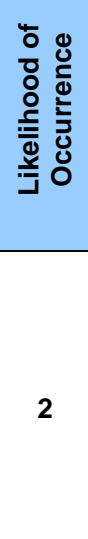 } & \multicolumn{2}{|c|}{ Impact } & $\begin{array}{c}\text { Overall } \\
\text { Risk } \\
\text { Rating }\end{array}$ \\
\hline \multirow{3}{*}{05.2 .1} & \multirow{3}{*}{$\mathrm{CHD}$} & \multirow{3}{*}{$\mathrm{TL}$} & \multirow{3}{*}{ USIPO } & \multirow{3}{*}{$\begin{array}{l}\text { If waveguide joint accuracy is not } \\
\text { adequate to ensure performance, then } \\
\text { there could be vacuum leaks, excessive } \\
\text { mode conversion, and efficiency losss. }\end{array}$} & & Technical & 3 & & & & & & & Technical & 1 & \multirow{3}{*}{ Medium } \\
\hline & & & & & & Schedule & 2 & & & & & & & Schedule & 1 & \\
\hline & & & & & & Cost & 2 & & & & & & & Cost & 2 & \\
\hline \multirow{3}{*}{05.2 .1} & \multirow{3}{*}{ CHD } & \multirow{3}{*}{$\mathrm{TL}$} & \multirow{3}{*}{$\begin{array}{l}10 / \\
\text { USIPO }\end{array}$} & \multirow{3}{*}{$\begin{array}{l}\text { If miter bend mirror precision is inadequate } \\
\text { for meeting acceptable mode purity } \\
\text { performance, then there could be } \\
\text { excessive mode conversion and efficiency } \\
\text { loss. }\end{array}$} & & Technical & 2 & & & & & & & Technical & 2 & \\
\hline & & & & & 4 & Schedule & 2 & High & Mitigate & $\begin{array}{l}\text { coordinate measurement machine } \\
\text { measurements to verify manufacturing }\end{array}$ & & & 2 & Schedule & 2 & Medium \\
\hline & & & & & & Cost & 2 & & & & & & & Cost & 2 & \\
\hline & & & & & & Technical & 2 & & & & & & & Technical & 2 & \\
\hline 05.2 .1 & $\mathrm{CHD}$ & $\mathrm{TL}$ & $\begin{array}{l}10 / \\
\text { USIPO }\end{array}$ & $\begin{array}{l}\text { If waveguide straightness and alignment is } \\
\text { inadequate, then there could be excessive } \\
\text { mode conversion and efficiency loss. }\end{array}$ & 4 & Schedule & 2 & High & Mitigate & $\begin{array}{l}\text { measurements, and alignment } \\
\text { techniques during prototype installation }\end{array}$ & & & 2 & Schedule & 2 & Medium \\
\hline & & & & & & Cost & 2 & & & & & & & Cost & 2 & \\
\hline
\end{tabular}




\section{Operational Risks}

\begin{tabular}{|c|c|c|c|c|c|c|c|c|c|c|c|c|c|c|c|c|}
\hline \multicolumn{8}{|c|}{ Title: EC Transmission Line risk log } & \multicolumn{9}{|c|}{ Procurement Arrangement: ECH PA 5.2.P2.US.01.0 } \\
\hline \multicolumn{17}{|c|}{ Responsible Manager: Gandini } \\
\hline & & & & & \multicolumn{4}{|c|}{ Revision Number: } & 0 & \multicolumn{7}{|l|}{ Date: January 2012} \\
\hline \multicolumn{9}{|c|}{ Risk Identification \& Evaluation } & \multicolumn{4}{|c|}{ Risk Disposition } & \multicolumn{4}{|c|}{ Risk Rating After Mitigation } \\
\hline \multirow{4}{*}{ 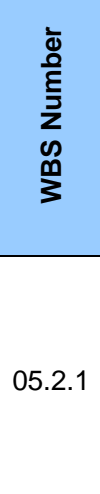 } & \multirow{4}{*}{ 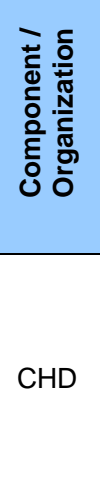 } & \multirow{4}{*}{ 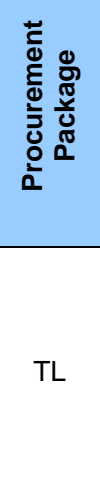 } & \multirow{4}{*}{$\begin{array}{c}\text { Risk } \\
\text { Owner } \\
\\
10\end{array}$} & Description of Risk & \multirow{4}{*}{ 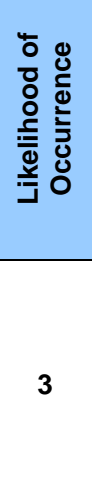 } & \multicolumn{2}{|c|}{ Impact } & $\begin{array}{c}\text { Overall } \\
\text { Risk } \\
\text { Rating }\end{array}$ & \multirow{4}{*}{ 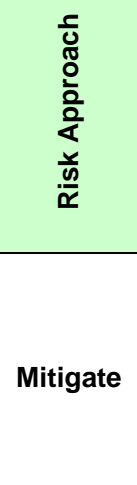 } & \multirow{4}{*}{\begin{tabular}{|l} 
Mitigation Strategy (Required for High \\
Level Risks)
\end{tabular}} & 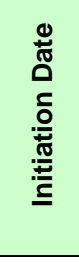 & 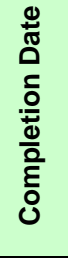 & \multirow{4}{*}{ 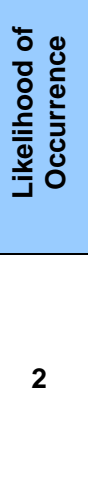 } & \multicolumn{2}{|c|}{ Impact } & $\begin{array}{c}\text { Overall } \\
\text { Risk } \\
\text { Rating }\end{array}$ \\
\hline & & & & \multirow{3}{*}{$\begin{array}{l}\text { If the EC_TL cooling circuit leaks } \\
\text { frequently then complicated maintenance } \\
\text { issues could result due to the large } \\
\text { number of cooling circuit joints. }\end{array}$} & & Technical & 1 & \multirow{3}{*}{ High } & & & & & & Technical & 1 & \multirow{3}{*}{ Medium } \\
\hline & & & & & & Schedule & 2 & & & & & & & Schedule & 2 & \\
\hline & & & & & & Cost & 2 & & & & & & & Cost & 1 & \\
\hline \multirow{3}{*}{05.2 .1} & \multirow{3}{*}{$\mathrm{CHD}$} & \multirow{3}{*}{ TL } & & If vacuum seals fail at unacceptably high & & Technical & 1 & & & Reliability of all-metal vacuum seals & & & & Technical & 1 & \\
\hline & & & 10 & $\begin{array}{l}\text { waveguide, an operational reliability issue } \\
\text { results and system availability gaals may }\end{array}$ & 3 & Schedule & 3 & High & Mitigate & $\begin{array}{l}\text { prevent operation with significant loss of } \\
\text { vacuum. Test stand vacuum system }\end{array}$ & & & 2 & Schedule & 1 & Low \\
\hline & & & & not be met & & Cost & 2 & & & help to establish design reliability. & & & & Cost & 1 & \\
\hline & & & & If Tritium leaks into a transmission line due & & Technical & 1 & & & $\begin{array}{l}\text { A tritium clean up plan needs to be } \\
\text { established and demonstrated on a test }\end{array}$ & & & & Technical & 1 & \\
\hline 05.2 .1 & $\mathrm{CHD}$ & $\mathrm{TL}$ & $\begin{array}{l}\text { IOI } \\
\text { USIPO }\end{array}$ & $\begin{array}{l}\text { to a window crack or braze flaw, then } \\
\text { system availability is impacted and }\end{array}$ & 3 & Schedule & 2 & Medium & Accept & $\begin{array}{l}\text { stand (without tritium) and at tritium test } \\
\text { stands on mock-up components. Isolate }\end{array}$ & & & 3 & Schedule & 2 & Medium \\
\hline & & & & & & Cost & 2 & & & ferrofluidic feedthroughs are acceptable. & & & & Cost & 1 & \\
\hline & & & & & & Technical & 1 & & & The transmission line must be designed & & & & Technical & 1 & \\
\hline 05.2 .1 & $\mathrm{CHD}$ & TL & $\begin{array}{l}\text { IO II } \\
\text { USIPO }\end{array}$ & $\begin{array}{l}\text { line, then system functionality could be } \\
\text { affected. }\end{array}$ & 3 & Schedule & 1 & Medium & Accept & $\begin{array}{l}\text { techniques. Demonstrations of removal } \\
\text { of various components from the system }\end{array}$ & & & 3 & Schedule & 1 & Medium \\
\hline & & & & & & Cost & 1 & & & test stands and other mock-ups. & & & & Cost & 1 & \\
\hline & & & & & & Technical & 1 & & & & & & & Cost & 1 & \\
\hline 05.2 .1 & CHD & TL & $\begin{array}{l}\text { II I } \\
\text { USIPO }\end{array}$ & $\begin{array}{l}\text { occurs during a seismic event, then } \\
\text { excessive down time might result when }\end{array}$ & 1 & Schedule & 2 & Low & Mitigate & $\begin{array}{l}\text { Design structures to accommodate } \\
\text { seismic events. Plan for adequate spare } \\
\text { parts for potential damage to waveguide. }\end{array}$ & & & 1 & Technical & 1 & Low \\
\hline & & & & & & Cost & 1 & & & & & & & Schedule & 1 & \\
\hline & & & & & & Technical & 2 & & & $\begin{array}{l}\text { Design supports to accommodate } \\
\text { thermal expansion IInvestiaate and }\end{array}$ & & & & Cost & 1 & \\
\hline 05.2 .1 & $\mathrm{CHD}$ & TL & 10 & $\begin{array}{l}\text { or thermal expansion occurs, then system } \\
\text { performance will suffer low efficiency and }\end{array}$ & 2 & Schedule & 1 & Medium & Mitigate & $\begin{array}{l}\text { develop a built-in mode purity monitor } \\
\text { using mode selective directional coupler. }\end{array}$ & & & 1 & Technical & 2 & Low \\
\hline & & & & & & Cost & 1 & & & launcher. & & & & Schedule & 1 & \\
\hline
\end{tabular}




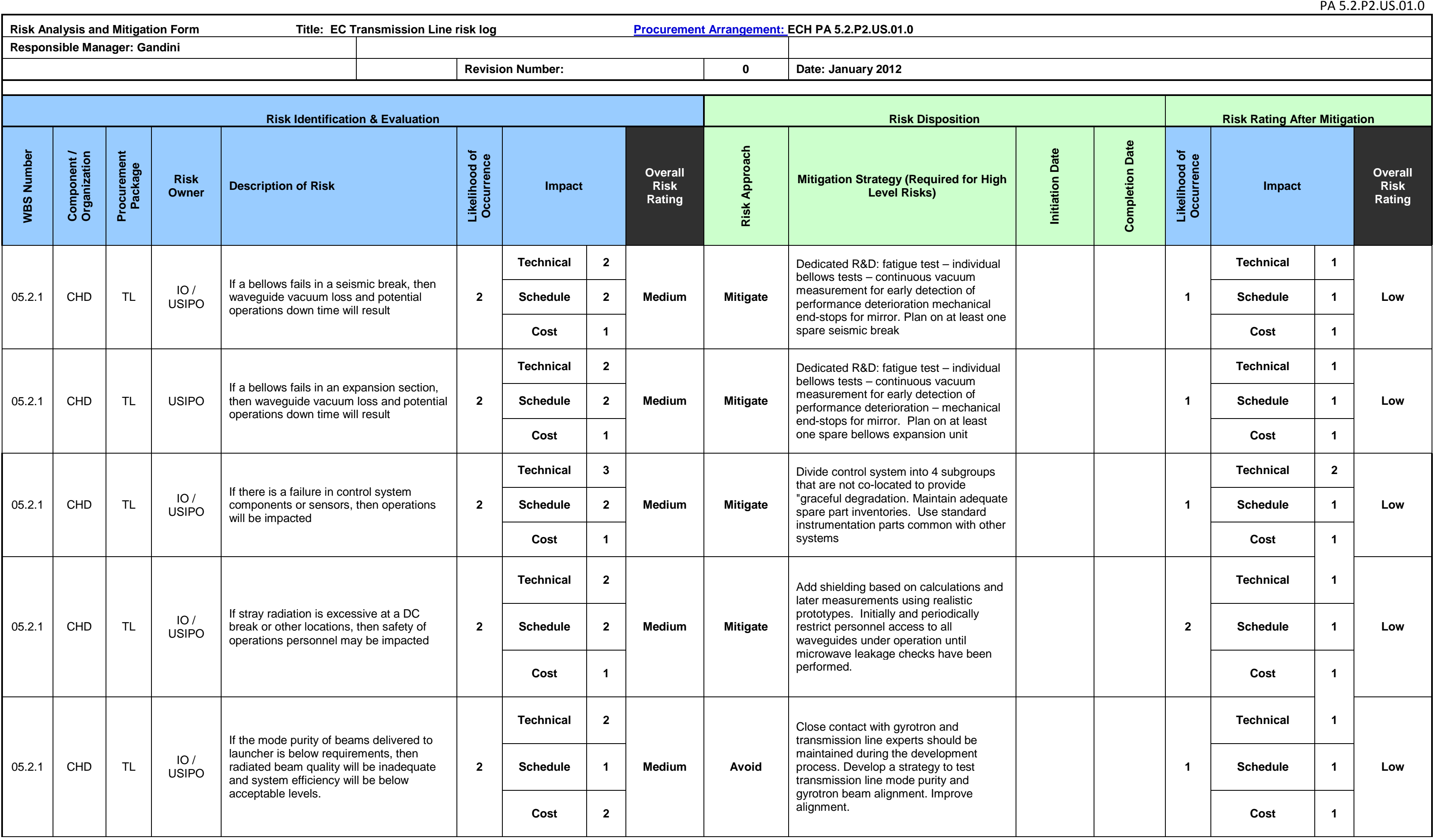




\section{Functional Risks}

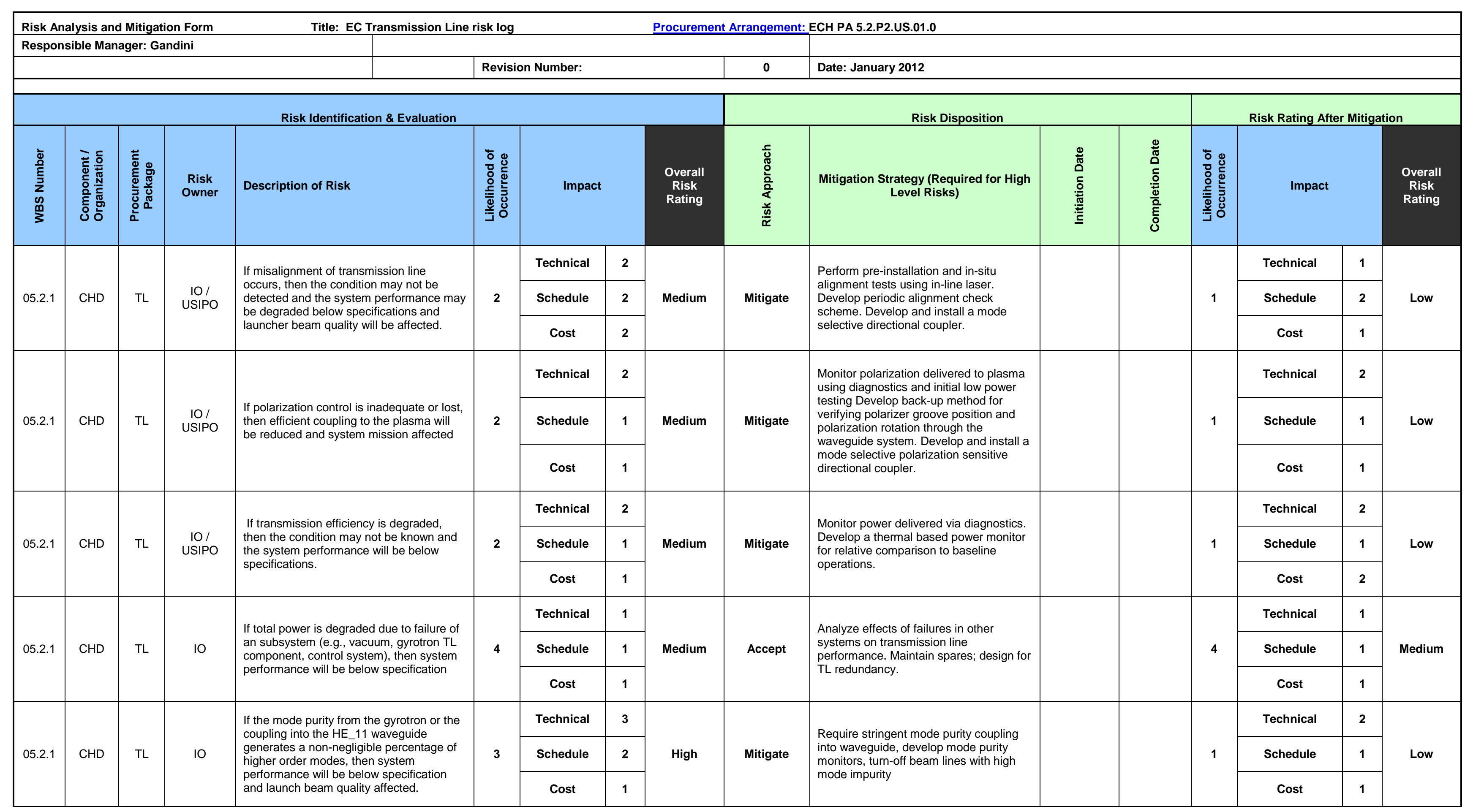




\section{REFERENCES}

[1] Procurement Arrangement 5.2.P2.US.01.0 ITER_D_2UY9XB

[2] Risk Management Plan (RMP) ITER_D_22F4LE v 2.0

[3] Risk Identification and Analysis Template ITER_D_2DLTYX_v1_1 